\title{
The Misunderstanding of Business Management Innovation in the Digital Economy Era Excess Merger and Corporate Innovation
}

\author{
Li Shuyan $^{1}$ \\ ${ }^{1}$ Beijing Jiaotong University, Department of Economics and Management, Beijing, China
}

\begin{abstract}
With the development of digital economy and technological innovation, many companies transform their model to improve market competitiveness. Some companies choose to achieve digital transformation through their own exploration, but more companies adapt to the change through large-scale mergers and acquisitions of technologically innovative companies, even cross-border mergers and acquisitions. Some companies want to integrate high-quality resources at the expense of excessive mergers and acquisitions, and eventually form the excess goodwill. However, whether such excess mergers and acquisitions can really promote corporate innovation still needs to be further explored. Through empirical research, this paper finds that excessive mergers and acquisitions do inhibit the innovation and development of enterprises, and then reveals the mechanism of action. This article reveals a misunderstanding of enterprise innovation and development, that is, the harm of excessive mergers and acquisitions to adapt to changes. It provides a new perspective for enterprises pursuing innovation, which is conducive to the management and development of innovative activities.
\end{abstract}

\section{Introduction}

The acceleration of technological development, especially artificial intelligence, Cognitive Computing, and the use of robots in more and more fields have promoted the transformation of technology and consumer behavior, forcing enterprises to promote innovation through crossindustry integration. A large number of companies use mergers and acquisitions to achieve rapid transformation and upgrading and seize innovation opportunities. Plenty of developing country companies are also beginning to acquire external knowledge through mergers and acquisitions to enhance their innovation capabilities. Mergers and acquisitions are not only the most rapid and effective growth strategy for enterprises, but also the most efficient response for enterprises to quickly acquire innovative resources in response to changes in business models (Ahuja and Katila, 2001)[1].

As an important asset of an enterprise, goodwill directly comes from the merger and acquisition of the enterprise. It reflects the expected synergy effect of the merged enterprise in the future. However, if the synergies of mergers and acquisitions cannot be brought into play, huge amounts of goodwill may hinder corporate innovation: on the one hand, the mergers and acquisitions of listed companies are not all rational. When mergers and acquisitions are not aimed at achieving synergies, excessive business Reputation (referred to as excess goodwill) will burden listed companies and make them lack resources to invest in research and development; on the other hand, excess goodwill may also lead to stakeholders such as banks, suppliers, customers, negative evaluation of the company's future operations, resulting in a decrease in the company's available resources for future operations, which are not conducive to the innovation and development of the company. It can be said that goodwill assets are undoubtedly a double-edged sword for companies-if the synergy effect after mergers and acquisitions is properly evaluated, moderate goodwill can give new vitality to the company's innovation; but if the synergy effect of mergers and acquisitions is overestimated, Excess goodwill may become a resistance to corporate innovation.

The current academic research on thousand goodwill mainly focuses on the definition[9], connotation[10] and measurement of goodwill[4] (Ramanna, 2008; Li et al., 2011; Glaum et al., 2018), the causes and influencing factors of goodwill (Johnson and Petrone, 1998), [7] and the economic consequences of goodwill (Yang Wei et al., 2018),[12] but few studies have explored how excess goodwill affects corporate innovation. In view of this, this article establishes multiple models to try to explore whether and how the excess goodwill of listed companies affects corporate innovation, so as to provide certain empirical evidence for understanding the economic consequences of excess goodwill and strengthening corporate innovation management. 
The study found that excess goodwill does inhibit the innovation of enterprises. Further analysis found that the mechanism of excess goodwill weakening the competitiveness of the company's product market may lie in the failure of excess goodwill to bring the necessary merger and acquisition synergies to the company, and it also consumes valuable resources for the development of the company.

\section{Research Hypothesis}

\subsection{Excess merger and corporate innovation.}

The motivation for corporate mergers and acquisitions is often to produce synergies through the integration of resources after mergers and acquisitions, so that the company's technical knowledge, management and marketing experience can be applied in more markets, which will help improve the efficiency of resource allocation. But the overestimated goodwill may become a burden for the company's continued operation. (Du Xingqiang et al. 2011)[11]believe that goodwill is expected to bring excess economic benefits to the company in the future, but such excess economic benefits are uncertain, and due to the existence of agency problems, company executives' over-optimistic and conceited mergers and acquisitions are often caused since goodwill is overvalued, it cannot reflect the nature of goodwill. The overvalued part cannot reflect the definition of assets, that is, excess economic benefits in the future. This article believes that excess goodwill arises from the company's overestimation of the synergies that the merger and acquisition can produce in the future resource integration, and the overestimation of the resource integration efficiency that goodwill assets can produce, thereby paying more than a reasonable level of merger consideration. It is the waste of scarce resources of the enterprise. Owning excess goodwill means that the target company is given excessively high valuations and premiums during mergers and acquisitions. This aspect not only leads to the reduction of the company's funds for production, research and development, and marketing, but also damages the company's continuous innovation. Driving force and influence the long-term development of the enterprise. Based on the above analysis, this paper proposes hypothesis $\mathrm{H} 1$ :

$\mathrm{H} 1$ : Excess merger has a negative impact on corporate innovation.

\subsection{Mechanism of excess merger to corporate innovation.}

This article believes that moderate M\&A goodwill may promote business operations through M\&A synergy, but overestimated excess goodwill may cause a waste of corporate resources. Firstly, excess goodwill consumes the scarce resources of the enterprise, resulting in insufficient resources available to the enterprise. Excess goodwill directly comes from high M\&A premiums, and premium M\&A wastes scarce resources, including human, material, and financial resources that could be used to enhance the company's innovation capabilities, directly leading to a decline in the company's innovation capabilities. For example, (Fresard, 2010)[3] found that a company's financial advantage, that is, holding a large amount of cash reserves relative to competitors can promote the development of enterprise innovation, and this effect will be magnified when competitors face financing constraints. Companies with sufficient cash have sufficient funds to support their innovative resource competition strategies, such as the construction of an effective logistics system, investment in advertising and $\mathrm{R} \& \mathrm{D}$, and investment in advanced equipment. (Campello, M., 2006)[5]. Secondly, excessive goodwill may lead to negative evaluations of the company by stakeholders, so that the resources available to the company for future development will be reduced and resource costs will be higher. So taht the company's stakeholders will lower their expectations of the company's business prospects and form a negative evaluation of the company. As a result, the stakeholders will reduce the supply of resources, or even if they provide resources, they will require higher risk compensation. The increase in the cost of acquiring resources will weaken the innovation ability of the enterprise. Based on the above analysis, this paper proposes hypothesis $\mathrm{H} 2$ :

H2: Excess merger will impact corporate innovation by weakening the company's growth ability and resource competitiveness.

\section{Research Design}

\subsection{Sample selection and data sources}

This paper selects 2007-2017 China A-share listed companies data as the initial research sample. The company patent application data used in this article comes from the China Research Data Service Platform (CNRDS). The financial data of listed companies mainly comes from the CSMAR database and the iFind financial terminal. The initial data are screened as follows: Delete financial listed companies; Remove ST Sample; Delete insolvent companies; Delete samples with less than 3 companies in the industry; Delete samples with missing key variables. In order to alleviate the influence of extreme values on the conclusions of this article, all continuous variables were Winsorized at the $1 \%$ and $99 \%$ quantiles. In order to alleviate the possible reverse causality problem, this article deals with all the interpretation changes at a lagging stage.

\subsection{Variable definition}

\subsubsection{Excess merger.}

Drawing on the practice of (Fu Chao et al. 2015)[13], this paper adopts the model prediction method to measure excess goodwill (GW ex), that is, the regression residual of the goodwill expectation model is used as the proxy variable of excess goodwill. Specifically, this article uses cash payment (cash), buyer expenditure value (lncost), the 
average value of other companies' goodwill in the industry (GW_norm), company size (Size), profitability (ROE), growth (Growth), management shareholding ratio (Maho), A series of indicators such as whether two jobs are integrated (Dual), industry and annual dummy variables are used to regress the company's goodwill level, and the residuals obtained from the regression are used as proxy variables for excess goodwill.

$$
G W_{\mathrm{i}, \mathrm{t}}=\alpha_{0}+\alpha_{1} \mathrm{cash}_{i, t}+\alpha_{2} \ln \cos \mathrm{t}_{i, t}+\alpha_{3} G W_{-} \text {norm }_{i, t}+\alpha_{4} \operatorname{Size}_{i, t}+\alpha_{5} R O E_{\mathrm{i}, \mathrm{t}}
$$$$
+\alpha_{5} \text { Growth }_{\mathrm{i}, \mathrm{t}}+\alpha_{6} \mathrm{Maho}_{i, t}+\alpha_{7} \text { Dual }_{i, t}+\sum \text { Year }+\sum \text { Industry }+\varepsilon_{i, t}
$$

\subsubsection{Enterprise innovation.}

The indicator used is the number of patent applications. The reason is: the number of patent applications, that is, the annual patent flow of a company, can instantly reflect the company's innovation activities in that year. According to the research of (Ahuja and Katila 2001)[1], patents reflect the company's technological innovation, and It is closely related to innovation output and is a knowledge asset with actual economic value.

\subsection{Variable description and descriptive statistics}

TABLE I. VARIABLE DESCRIPTION AND DESCRIPTIVE STATISTICS

\begin{tabular}{|c|c|c|c|}
\hline \multirow{2}{*}{ Variable } & \multirow{2}{*}{ Definition } & \multicolumn{2}{|c|}{$\begin{array}{c}\begin{array}{c}\text { Description } \\
(\mathrm{N}=\mathbf{8 6 5 4})\end{array} \\
\end{array}$} \\
\hline & & Mean & $\begin{array}{l}\text { Standard } \\
\text { Deviation }\end{array}$ \\
\hline Lnpat & $\begin{array}{l}\text { Add } 1 \text { to the number of the } \\
\text { patent application and take } \\
\text { the natural logarithm }\end{array}$ & 1.9760 & 1.7440 \\
\hline GW_ex & $\begin{array}{l}\text { The regression residual of the } \\
\text { goodwill expectation mode }\end{array}$ & 0.0001 & 0.0650 \\
\hline Size & Logarithm of total assets & 21.8255 & 1.1953 \\
\hline Age & $\begin{array}{l}\ln (1+\text { current year-year of } \\
\text { establishment })\end{array}$ & 2.6725 & 0.4642 \\
\hline LEV & $\begin{array}{l}\text { The ratio of total liabilities to } \\
\text { total assets at the end of the } \\
\text { year }\end{array}$ & 0.4248 & 0.2085 \\
\hline Revgrowth & $\begin{array}{l}\text { (current operating income-last } \\
\text { operating income) / last } \\
\text { operating income }\end{array}$ & 0.2078 & 0.5960 \\
\hline $\begin{array}{c}\text { Indepen- } \\
\text { dence }\end{array}$ & $\begin{array}{lll}\begin{array}{l}\text { Number } \\
\text { directors }\end{array} & \text { of independent } \\
\end{array}$ & 0.3752 & 0.0680 \\
\hline HHI & $\begin{array}{l}\text { The square sum of the } \\
\text { company's operating income } \\
\text { as a percentage of the } \\
\text { industry's total income }\end{array}$ & 0.1045 & 0.1098 \\
\hline Growth & Company growth & 0.2366 & 0.6220 \\
\hline PPE & Fixed assets/total assets & 0.2213 & 0.1608 \\
\hline Boardsize & $\begin{array}{l}\text { Total number of board } \\
\text { members }\end{array}$ & 8.6446 & 1.6458 \\
\hline Maho & $\begin{array}{l}\text { Management shareholding } \\
\text { ratio }\end{array}$ & 0.1370 & 0.2098 \\
\hline Dual & $\begin{array}{l}\text { The two positions of chairman } \\
\text { and CEO are combined, the } \\
\text { value is } 1 \text {, otherwise it is } 0\end{array}$ & 0.2794 & 0.4487 \\
\hline SOE & $\begin{array}{l}\text { if the property right is a state- } \\
\text { owned enterprise, assign a } \\
\text { value of } 1 \text {, otherwise it is } 0\end{array}$ & 0.3592 & 0.4798 \\
\hline Share & $\begin{array}{l}\text { Operating income / total } \\
\text { industry operating income for } \\
\text { the year }\end{array}$ & 0.0176 & 0.0458 \\
\hline TQ & Tobin Q & 2.2112 & 1.4800 \\
\hline $\mathrm{KZ}$ & Financing constraints & 1.0122 & 2.4400 \\
\hline
\end{tabular}

\subsection{Empirical model}

This paper constructs the following empirical OLS model: Lnpat $_{i, t}=\beta_{0}+\beta_{1} G W_{-}$ex $_{i, t}+\beta_{2}$ Size $_{i, t}+\beta_{3}$ Age $_{i, t}+\beta_{4} L E V_{i . t}$

$+\beta_{5}$ Re vgrowth $_{i, t}+\beta_{6}$ Independence $_{i, t}+\beta_{6}$ HHI $_{i, t}+\beta_{7}$ Growth $_{i, t}+\xi_{i, t}$

In the model(2), the dependent variable lnpat represents the company's innovation output, which is replaced by the number of patent applications in the next one, two and three years respectively; refer to previous studies (Fang et al., 2014) [2], the empirical model controls a series of characteristic variables of executives, enterprises and industries that may affect innovation. If the regression coefficient of GW_ex in model (2) is also significantly negative, it means that excess goodwill has a significant negative impact on corporate innovation. Therefore, excess goodwill does become a corporate operating burden, that is, Hypothesis H1 is empirically supported.

\section{Empirical Analysis}

\subsection{Baseline results}

TABLE II. EXCESS MERGER AND CORPORATE INNOVATION

\begin{tabular}{|c|c|}
\hline & Lnpat \\
\hline GW_ex & $\begin{array}{c}-0.9804 * * \\
(-1.96)\end{array}$ \\
\hline Size & $\begin{array}{c}0.0480 \\
(1.56)\end{array}$ \\
\hline Age & $\begin{array}{c}0.2969 * * * \\
(3.78)\end{array}$ \\
\hline LEV & $\begin{array}{c}-0.3205^{*} \\
(-1.81)\end{array}$ \\
\hline Revgrowth & $\begin{array}{c}-0.1263 * * \\
(-2.42)\end{array}$ \\
\hline Independence & $\begin{array}{c}1.0237 * * \\
(2.12)\end{array}$ \\
\hline HHI & $\begin{array}{c}-1.5234 * * * \\
(-5.23)\end{array}$ \\
\hline Growth & $\begin{array}{c}-0.0311 \\
(-0.62)\end{array}$ \\
\hline _cons & $\begin{array}{c}0.0528 \\
(0.08) \\
\end{array}$ \\
\hline $\mathrm{N}$ & 2876 \\
\hline R2 & 0.0223 \\
\hline $\mathrm{F}$ & 8.1704 \\
\hline $\mathrm{p}$ & 0.0000 \\
\hline
\end{tabular}

Table II reports the results of the empirical test of Hypothesis H1. Table II shows that the regression coefficient of excess goodwill (GW_ex) to corporate innovation (Lnpat) is significantly negative at the 5\% level. From an economic point of view, for every additional unit of excess goodwill, corporate innovation (Lnpat) drops by about 0.98 , which has a greater impact on economic significance. It can be seen that the hypothesis $\mathrm{H} 1$ in this article is empirically supported. The above empirical results show that excess goodwill does 
have a significant negative impact on the innovation capability of enterprises.

\subsection{Robust test}

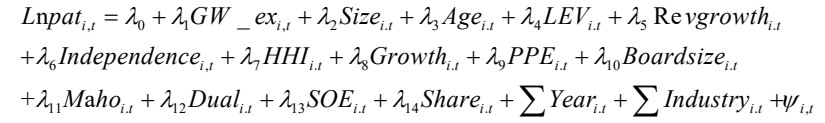

TABLE III. RoBUSt Test

\begin{tabular}{lc}
\hline & Lnpat \\
\hline GW_ex & $-0.8425^{*}$ \\
& $(-1.67)$ \\
cons & 0.5335 \\
& $(0.59)$ \\
Controls & - \\
Industry & Control \\
Year & Control \\
\hline $\mathrm{N}$ & 2876 \\
$\mathrm{R}^{2}$ & 0.1024 \\
$\mathrm{~F}$ & 4.6581 \\
$\mathrm{p}$ & 0.0000 \\
\hline
\end{tabular}

$$
{ }^{*} p<0.1,{ }^{t * *} p<0.05,{ }^{* * *} p<0.01
$$

The robust test adopts the method of controlling the industry and the year, as well as the use of robust standard errors for regression. The results are shown in Table III, the regression coefficient of excess goodwill (GW_ex) to corporate innovation (Lnpat) is still significantly negative at the $10 \%$ Level. Shows that the results are robust.

\subsection{Supplement tests: The mechanism of excess merger impact enterprise innovation

$$
T Q_{\mathrm{i}, \mathrm{t}} / K Z_{i, t}=\gamma_{0}+\gamma_{1} G W_{-} \text {ex }_{i, t}+\sum \gamma_{n} \text { Controls }_{i, t}+\delta_{i, t}
$$

\subsubsection{Does the excess goodwill bring the necessary merger and acquisition synergies to the enterprise.}

Existing literature finds that one of the manifestations of synergy is that the merged joint enterprise has higher growth (Hoberg and Phillips, 2010)[6]. Tobin's Q value (TQ) is selected as a measure of corporate growth to study whether excess goodwill improves corporate growth in the future.

The first column of Table IV. shows that excess goodwill (GW_ex) and Tobin's Q (TQ) are significantly negatively correlated at the level of 5\%; this indicates that excess goodwill has a significant negative effect on the company's Tobin Q value. Therefore, the excess goodwill not only failed to promote the development of the company, but hindered the growth of the company to a certain extent, that is, the synergy of mergers and acquisitions has not been realized.

\subsubsection{Does the excess merger consume the scarce resources of the enterprise.}

Excess goodwill comes from the high premium paid to the target company during mergers and acquisitions. The higher the excess goodwill means the more resources that the company could use for production, $R \& D$, and marketing are wasted. This article draws on (Lamont et al. 2001),[8] use the $\mathrm{KZ}$ index to measure the degree of financing constraints faced by companies. The larger the $\mathrm{KZ}$ index, the more severe the financing constraints of the company.

The second column of Table 3 shows that the regression coefficient of excess goodwill (GW_ex) is significantly positive at the $1 \%$ level. The empirical results show that the excess goodwill does consume the precious resources of the company and makes the company face more severe financing constraints, that is, the excess goodwill will reduce the innovation ability of the company by consuming corporate resources.

In conclusion, this part of the empirical results verifies Hypothesis $\mathrm{H} 2$.

TABLE IV. THE MECHANISM OF EXCESS GOODWILL IMPACT ENTERPRISE INNOVATION

\begin{tabular}{lcc}
\hline & $(1)$ & $(2)$ \\
& TQ & KZ \\
\hline GW_ex & $-0.9215^{* *}$ & $2.9517^{* * *}$ \\
& $(-2.33)$ & $(6.58)$ \\
cons & $16.8333^{* * *}$ & $8.6377^{* * *}$ \\
& $(19.82)$ & $(9.98)$ \\
Controls & - & - \\
Industry & $0.3607^{*}$ & 0.1564 \\
Year & 0.1220 & $0.4314^{* *}$ \\
& $(0.75)$ & $(2.31)$ \\
\hline $\mathrm{N}$ & 2876 & 2876 \\
$\mathrm{R}^{2}$ & 0.4064 & 0.5803 \\
$\mathrm{~F}$ & 15.1733 & 50.1974 \\
$\mathrm{p}$ & 0.0000 & 0.0000 \\
\hline \multicolumn{2}{c}{$t$ statistics in parentheses $^{* * *} p<0.01$}
\end{tabular}

\section{Conclusion}

In recent years, Chinese corporate M\&A transactions have grown rapidly, but many corporate M\&As have been criticized for their unsatisfactory resource integration and performance, and the excess merger generated in the process of mergers and acquisitions of some companies has resulted in post-merger innovation. The decline affects the long-term development of the company. This paper verify that the excess merger has a significant negative impact on the company's innovation capability, that is, the excess merger does become a business burden for the company. The extended research part further reveals the possible mechanism and governance mechanism of excess merger weakening the innovation ability of the company. Excess merger causes the company to waste scarce resources and reduces the growth of the company, and the stakeholder theory makes the problem of corporate financing constraints more 
serious, increasing the debt financing cost of enterprises. This paper suggests that listed companies should reasonably evaluate the promotion of mergers and acquisitions in the integration of corporate resources, avoid blind mergers and acquisitions, and make mergers and acquisitions truly serve the needs of the company's innovation and development.

\section{Acknowledgment}

The completion of the thesis is inseparable from the guidance of the tutor, the encouragement of the parents and the mutual exchanges between friends. Thanks to my professor, my parents, especially my roommates for the company and help, so that I have the motivation to continue to grow in the academic field.

\section{References}

1. Ahuja, G., and R. Katila. 2001. Technological Acquisitions and the Innovation Performance of Acquiring Firms: A Longitudinal Study. Strategic Management Journal, 22(3): 197-220.

2. Fang, V. W., X. Tian, and S. Tice. Does Stock Liquidity Enhance or Impede Firm Innovation [J]. Journal of Finance, 2014,69(5) :2085-2125.

3. Fresard, L. 2010. Financial Strength and Product Market Behavior: The Real Effects of Corporate Cash Holdings. The Journal of Finance (New York), 65(3): 1097-1122.

4. Glaum, M., W. R. Landsman, and S. Wyrwa. 2018. Goodwill Impairment: The Effects of Public Enforcement and Monitoring by Institutional Investors. The Accounting Review, 93(6): 149-180.

5. Campello, M. Debt Financing: Does It Boost Or Hurt Firm Performance in Product Markets? Journal of Financial Economics. 2006, 82(1): 135-172.

6. Hoberg, G., and G. Phillips. Product Market Synergies and Competition in Mergers and Acquisitions:A Text-Based Analysis[J]. Review of Financial Studies, 2010,23(10) :3773-3811.

7. Johnson, L. T., and K. R. Petrone. Commentary:ls Goodwill an Asset[J]. Accounting Horizons, 1998,12(3):293-303.

8. Lamont, 0., C. Polk, and J. Saa-Requejo. Financial Constraints and Stock Retums[J]. Review of Financial Studies, 2001,14(2):529-554.

9. Ramanna, K. The Implications of Unverifiable Fairvalue Accounting: Evidence from the Political Economy of Goodwill Accounting[J]. Journal of Accounting and Economics, 2008, 45 (2-3): 253-281.

10. Li Danmeng, Ye Jianfang, Lu Siqi. Management overconfidence, property rights and M\&A goodwill[J]. Accounting Research, 2018, (10): 50-57.

11. Du Xingqiang, Du Yingjie, Zhou Zejiang. Discussion on the connotation of goodwill and its
confirmation[J]. Accounting Research, 2011, (01): 11-16.

12. Yang Wei, Song Min, Feng Ke. M\&A goodwill, investor overreaction and stock price bubble and collapse[J]. China Industrial Economy, 2018, (06): 156-173.

13. Fu Chao, Yang Zeng, Fu Daiguo. Does the "Peer Effect" Affect the Goodwill of Enterprises' M\&A?- Based on the Empirical Evidence of my country's GEM High Premium M\&A[J]. China Soft Science, 2015, (11): 94-108 . 